\title{
Hypernatraemia with reset osmostat associated with secondary hypogonadism
}

\author{
Yasir Mohamed Elhassan ${ }^{1}$, Richard Ross ${ }^{1,2}$, Jonathan Webster1 \\ ${ }^{1}$ Sheffield Teaching Hospitals NHS Trust, ${ }^{2}$ University of Sheffield
}

\section{Introduction}

We report two cases of hypernatraemia with reset osmostat and evidence of abnormal pituitary function.

\section{Case 1}

- A 35-year-old male was referred with Graves' thyrotoxicosis associated with hypokalaemic periodic paralysis and an incidental finding of serum sodium $154 \mathrm{mmol} / \mathrm{L}$

- He complained of a long history of polyuria and nocturia, denied excessive thirst and was otherwise well

- Height was $193 \mathrm{~cm}$ with BMI 29.5

- He had gynaecomastia and sparse body hair

- He had a small $6 \mathrm{ml}$ right testicle (originally undescended) and $15 \mathrm{ml}$ left testicle

- A very high arched, possibly cleft palate was noted suggesting a midline defect (Figure 1)

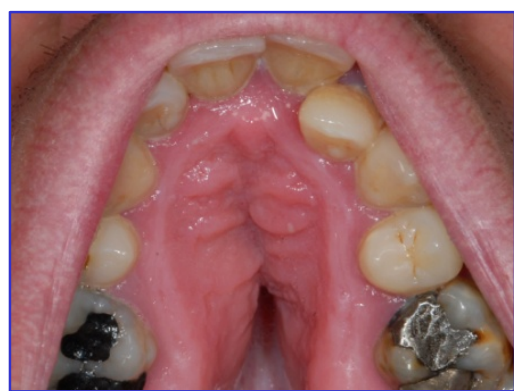

Figure 1. High arched palate

\section{Investigations}

- Serum osmolality was $314 \mathrm{mOsm} / \mathrm{kg}$ with urine osmolality $1025 \mathrm{mOsm} / \mathrm{kg}$

- Testosterone 5.0nmol/L (9.9-27.8), LH 5.6IU/L (1.7-8.6) and FSH 5.0IU/L (1.2-12)

- Prolactin, IGF-1, synacthen test, renin and aldosterone were normal

- Pituitary MRI was normal

- He had undergone a water load/deprivation test (Table 1)

\begin{tabular}{|l|l|l|l|}
\hline Time & $\begin{array}{l}\text { Plasma } \\
\text { Osmolality } \\
(\mathrm{mmol} / \mathrm{kg})\end{array}$ & $\begin{array}{l}\text { Urine } \\
\text { Osmolality } \\
(\mathrm{mmol} / \mathrm{kg})\end{array}$ & $\begin{array}{l}\text { Plasma AVP } \\
(\mathrm{pg} / \mathrm{ml})\end{array}$ \\
\hline $10: 00$ & 303 & 891 & 1.3 \\
$11: 00$ & & 387 & \\
\hline $12: 00$ & & 245 & \\
\hline $13: 00$ & & 462 & \\
\hline $14: 00$ & 304 & 866 & 2.5 \\
\hline $15: 00$ & & 916 & \\
\hline $16: 00$ & & 946 & \\
\hline $17: 00$ & 304 & 930 & 2.4 \\
\hline
\end{tabular}

Table 1. The water load/deprivation test shows a prompt reduction in urine osmolality in response to the water load and urine concentration then increased during subsequent fluid deprivation. There is reasonable evidence of osmoregulatory control over AVP.

\section{Case 2}

- An 18-year-old male was admitted following an incidental finding of serum sodium $163 \mathrm{mmol} / \mathrm{L}$ whilst being investigated for joints pain

- He otherwise feels well and denied excessive thirst or polyuria

- Examination showed BMI 40.4, short stature $(154 \mathrm{~cm})$, small hands, size 6 feet and gynaecomastia

- Testicular volumes were $15 \mathrm{ml}$ bilaterally

\section{Investigations}

- Serum osmolality was $330 \mathrm{mOsm} / \mathrm{kg}$, urine osmolality $731 \mathrm{mOsm} / \mathrm{kg}$ and urine sodium $172 \mathrm{mmol} / \mathrm{L}$

- Initial hospital treatment with 5\% Glucose reduced his serum sodium to $152 \mathrm{mmol} / \mathrm{L}$ and urine osmolality to $114 \mathrm{mOsm} / \mathrm{kg}$ His urine output increased to 3 litres/day whilst he remained hyperosmolar with a calculated serum osmolality of $316 \mathrm{mOsm} / \mathrm{kg}$

- Prolactin was $2000 \mathrm{mIU} / \mathrm{L}$ (86-324), LH 6.3IU/L (1.7-8.6), FSH 1.0IU/L (1.2-12) and Testosterone 5.7nmol/L (9.9-27.8)

- IGF-1 was low with peak GH 4.5ug/L on ITT

- TSH, FT4 and synacthen test were normal

- Pituitary MRI was normal

\section{Discussion}

- Both cases of hypernatraemia were incidentally found in asymptomatic patients

- Increased urine output and reduced urine osmolality following a fluid load was demonstrated in both cases whilst they remained hypernatraemic and hyperosmolar

- In the first case, there was direct evidence of osmoregulatory control over AVP levels consistent with reset osmostat

- In both cases there was evidence of pituitary dysfunction

- A congenital midline defect is the most likely cause in the first case

- The second patient has been commenced on dopamine agonist therapy

- Both patients have been maintained on a fixed daily fluid intake

\section{Conclusion}

- "Essential hypernatraemia" is rare and usually secondary to traumatic brain injury or surgery

- It represents a complex diagnostic challenge which needs to be made to avoid subsequent misinterpretation of the fluid status 